\title{
Penguatan Pendidikan Karakter Nilai Religius Dalam Program Kegiatan Budaya Sekolah
}

\author{
Annek Astri Octaviani ${ }^{1}$, Furaidah ${ }^{2}$, Sri Untari ${ }^{3}$ \\ ${ }^{1}$ Pendidikan Dasar-Universitas Negeri Malang \\ ${ }^{2}$ Pendidikan Bahasa Inggris-Universitas Negeri Malang \\ ${ }^{3}$ Pendidikan Kewarganegaraan-Universitas Negeri Malang
}

\begin{tabular}{l} 
INFO ARTIKEL \\
\hline Riwayat Artikel: \\
Diterima: 28-06-2019 \\
Disetujui: 18-11-2019 \\
\hline
\end{tabular}

\section{Kata kunci:}

strengthening character education; religious character;

school culture;

penguatan pendidikan karakter;

karakter religius;

budaya sekolah

\begin{abstract}
This research aims to describe the program's cultural activities as a deciding of the quality of the school. This research uses qualitative research methods with descriptive type. The results of this research, namely, programs for strengthening the character education religious values that exist in the school consist of extracurricular, cocurricular and cultural school. But the quality of a school is determined from the culture of the schools it has set. This is because the program of extracurricular and co-curricular activities is not every day executed by learners. So that the character resulting from the program of extracurricular and co-curricular activities is not as much as the program of school culture activities that are applied everyday.

Abstrak: Penelitian ini bertujuan untuk mendeskripsikan program-program kegiatan budaya sekolah sebagai penentu dari mutu sekolah. Penelitian ini menggunakan metode penelitian kualitatif dengan jenis deskriptif. Hasil penelitian ini, yaitu program-program kegiatan penguatan pendidikan karakter nilai religius yang ada di sekolah terdiri dari krgiatan ekstrakurikuler, co-kurikuler, dan budaya sekolah. Akan tetapi, mutu dari sebuah sekolahan tersebut ditentukan dari budaya sekolah yang diterapkannya. Hal tersebut dikarenakan pada program kegiatan ekstrakurikuler dan co-kurikuler tidak setiap hari dijalankan oleh peserta didik. Jadi, karakter yang dihasilkan dari program kegiatan ekstrakurikuler dan co-kurikuler tidak semaksimal program kegiatan budaya sekolah yang diterapkan setiap hari.
\end{abstract}

ABSTRAK

\author{
Alamat Korespondensi: \\ Annek Astri Octaviani \\ Pendidikan Dasar \\ Universitas Negeri Malang \\ Jalan Semarang 5 Malang \\ E-mail: annekastrioctaviani@gmail.com
}

Kemajuan pendidikan menjadi faktor keberhasilan suatu bangsa. Pendidikan nasional mempunyai tujuan untuk menumbuhkembangkan potensi peserta didik agar menjadi manusia yang beriman dan bertakwa kepada Tuhan Yang Maha Esa, berakhlak mulia, sehat, berilmu, cakap, kreatif, mandiri, dan menjadi warga negara yang demokratis serta bertanggung jawab (Undang-undang Republik Indonesia Nomor 20, 2003). Calon pendidik di lingkungan pendidikan dasar mempunyai peran yang sangat besar dalam pertumbuhan karakter peserta didik. Hal tersebut dikarenakan pendidikan dasar menjadi pondasi utama untuk membentuk karakter peserta didiknya. Oleh karena itu, pendidikan karakter menjadi hal yang penting karena pendidikan tidak hanya menjadikan peserta didik menjadi cerdas, tetapi juga mempunyai sopan santun dan budi pekerti (Ramli, 2011).

Mengingat pentingnya penanaman nilai-nilai karakter pada anak, maka sudah sepatutnya hal tersebut dilakukan sejak dini, bahkan sebelum anak belajar mengenai kompetensi-kompetensi pembelajaran terkait. Hal ini sejalan dengan pendapat Ganiere, Howell and Osguthorpe (2007) yang menjelaskan bahwa pendidikan sudah seharusnya mendahulukan penanaman karakter sebelum melangkah lebih jauh pada kompetensi-kompetensi yang diinginkan. Lebih jauh lagi, mereka sepakat bahwa penanaman karakter sangat diperlukan untuk membentuk pribadi yang dibutuhkan abad ke- 21.

Bangsa Indonesia memiliki banyak nilai karakter yang sudah mendarah daging bagi sebagian besar kalangan terutama kalangan pendidikan. Nilai-nilai karakter yang dikembangkan di Indonesia bersumber dari agama, Pancasila, budaya, dan tujuan pendidikan nasional. Lima karakter utama bangsa Indonesia adalah religius, nasionalis, mandiri, gotong royong, dan integritas. Lima nilai-nilai utama tersebut disesuaikan dengan Gerakan Nasional Revolusi Mental, kearifan lokal, dan kreativitas sekolah (Tim penyusun PPk, 2017). Berdasarkan hal tersebut, setiap peserta didik di Indonesia dituntut untuk memiliki kelima karakter yang utama guna mendukung keberhasilan pendidikan di Indonesia. 
Perkembangan pada era globalisasi saat ini adalah bentuk dari segala perubahan, seperti teknologi yang semakin berkembang. Perkembangan ini membawa perubahan yang besar pada semua sisi kehidupan manusia termasuk pada bidang pendidikan. Kecanggihan teknologi membuat pembelajaran menjadi semakin mudah dan menarik. Pembelajaran dapat dilakukan dimanapun serta kapanpun. Namun, selain membawa dampak positif era globalisasi juga membawa dampak negatif yang besar. Pemanfaatan teknologi yang kurang bijak dapat membawa dampak negatif pada masyarakat khususnya pada anak-anak. Banyak sekali bermunculan mengenai perilaku peserta didik yang menyimpang, seperti tawuran antar pelajar, bullying, melawan orangtua, guru, dan tindak kejahatan lainnya (Samani, 2011).

Kenyataan tersebut banyak menjadi sorotan di masyarakat. Ditambah lagi semakin banyaknya kasus-kasus amoral yang terjadi di sekolah, seperti bullying, siswa yang berani kepada gurunya serta yang lainnya membuat pemerintah perlu untuk mencanangkan Penguatan Pendidikan Karakter. Penguatan Pendidikan Karakter merupakan gerakan pendidikan di bawah tanggung jawab satuan pendidikan untuk memperkuat karakter peserta didik melalui harmonisasi olah hati, olah rasa, olah pikir, dan olahraga dengan pelibatan dan kerja sama antar satuan pendidikan, keluarga, dan masyarakat sebagai bagian dari Gerakan Nasional Revolusi Mental (GNRM) (Ditjen Pendidikan Dasar dan Menengah, 2017). Program penguatan pendidikan karakter dijalankan pada jenjang pendidikan dasar, dan akan terus diperkuat hingga pendidikan menengah untuk semakin memantapkan nilai-nilai karakter peserta didik di Inonesia. Dengan adanya program penguatan pendidikan ini pemerintah berharap berbagai permasalahan-permasalahan tersebut dapat diatasi secara bertahap.

Karakter itu tidak dapat dikembangkan secara segera atau instan, tetapi harus melalui proses yang panjang, sistematis, dan cermat. Dalam prosesnya manusia mengalami proses pendidikan karakter sejak usia dini hingga dewasa melalui tahapan-tahapan yang berkelanjutan (Aeni, 2014). Tahapan-tahapan perkembangan pada anak dipengaruh oleh berbagai faktor baik secara internal maupun secara eksternal. Faktor eksternal yang sangat berpengaruh yaitu lingkungan baik lingkungan keluarga maupun lingkungan sekolah, seperti interaksi dengan teman sebaya dan belajar (Hurlock, 2006). Berdasarkan hal tersebut sekolah mempunyai peran yang penting dalam perkembangan anak yang berarti sangat penting pula dalam pembentukan karakter anak. Hal ini sesuai dengan (Mendiknas, 2010) yaitu pembentukan karakter anak yang tepat ketika ia masih duduk di bangku Sekolah Dasar.

Sebagaimana telah disebutkan sebelumnya bahwa karakter bangsa Indonesia salah satunya bersumber pada nilai-nilai agama, maka pendidikan di sekolah perlu menyelenggarakan pendekatan-pendekatan dalam pendidikan yang berbasis keagamaan. Kompetensi spiritual pada jenjang pendidikan dicapai melalui pembelajaran tidak langsung (Indirect Teaching), diantaranya adalah keteladanan, pembiasaan, dan budaya sekolah, dengan mengacu pada karakteristik mata pelajaran, serta kondisi dan kebutuhan peserta didik. Pembiasaan karakter berbasis budaya sekolah diantaranya pembiasaan nilai-nilai dalam keseharian sekolah, keteladanan pendidik, melibatkan seluruh ekosistem pendidikan di sekolah, dan mempertimbangkan norma, peraturan, dan tradisi sekolah. Pembiasaan merupakan upaya yang dapat dilakukan dalam pendidikan karakter. Apabila pembiasaan dilakukan secara terus menerus dan berkelanjutan, maka akan tampak kebudayaan yang sudah diterapkan. Hal ini sejalan dengan pendapat (Ramdhani, 2013), menyatakan bahwa Penciptaan lingkungan yang kondusif salah satunya melalui pembiasaanpembiasaan dalam penguatan pendidikan karakter. Pentingnya penguatan pendidikan karakter melalui pembiasaan-pembiasaan dalam budaya sekolah, juga untuk menanggulangi adanya penurunan moral di kalangan anak-anak dianggap sebagai cermin kurang berhasilnya dunia pendidikan di era globalisasi sekarang ini (Inanna, 2018).

Saat ini sudah mulai banyak sekolah yang menjadikan agama sebagai dasar dari program-program di sekolahnya, salah satunya adalah SD Alam Ar-Rohman yang berada di kota Malang. Sekolah Ar-Rahman merupakan sekolah alam, namun menggunakan Tauhid sebagai dasar program-program di sekolahnya sehingga disebut pula sekolah Tauhid. Sekolah ini telah banyak mencetak prestasi dalam bidang keagamaan. Berdasarkan observasi pendahuluan yang dilakukan oleh peneliti di SD Alam Ar-Rohmah Malang pada bulan Juli 2019. Dari hasil pengamatan peneliti di SD Alam Ar-Rohmah Malang memiliki pembiasaanpembiasaan yang membentuk karakter peserta didik. Pembiasaan tersebut tidak hanya berlaku dan dilaksanakan oleh siswa, namun juga dilakukan oleh guru dan kepala sekolah. Pada pagi hari siswa dibiasakan untuk berjabat tangan dan mengucapkan salam kepada guru piket yang sudah menunggu di gerbang sekolah, sebelum masuk kelas siswa berdoa, sebelum memulai pembelajaran siswa berdoa terlebih dahulu. Pada jam yang telah ditentukan maka siswa akan melakukan sholat dhuha berjamaah. Siang harinya siswa melakukan sholat dhuhur berjamaah. Sholat dhuhur dilakukan bersama dengan guru dan staf sekolah.

Berbagai jenis program pembiasaan tersebut dilakukan guna mengurangi pelanggaran-pelanggaran perilaku yang banyak dilakukan oleh siswa. kepala sekolah beserta seluruh guru mencoba untuk memperbaiki perilaku siswa melalui karakter religius yang bersumber kepada Tuhan. Hal ini sejalan dengan pendapat (Retnanto, 2013) yang menyatakan jika keagamaan dan kemanusiaan digunakan sebagai dasar kearifan untuk mencari cara pemecahan masalah disamping cara yang bersifat ilmiah pragmatis. Selain itu (Ri'ayah, 2016) mengatakan seorang siswa perlu untuk memahami mengenai nilai-nilai dari pembelajaran dilakukan sehingga anak karakter baik anak akan lebih mudah muncul. ada beberapa strategi yang dapat dilakukan, salah satunya yaitu menghubungkan antara moral dan religius siswa. 


\section{METODE}

Jenis penelitian ini adalah kualitatif deskriptif. Peneliti hadir di lokasi penelitian sebagai pengamat non-partisipan. Penelitian dilakukan di SD Alam Ar-Rohman Malang karena sekolah tersebut menerapkan program pembiasaan karakter religius dengan sangat baik, dibuktikan dengan dampak dari program yang ditimbulkan pada siswa. Pengumpulan data dari sumber data dilakukan dengan beberapa teknik, yaitu observasi, wawancara, dan dokumentasi kepada subjek-subjek terkait.

Analisis data data dalam penelitian menggunakan teknik analisis menurut (Huberman, 1992) yaitu pengumpulan data, model data, penyajian data, reduksi data, serta penarikan kesimpulan/verifikasi. Keseluruhan kegiatan tersebut dilakukan secara interaktif dan terus menerus hingga data mencapai titik jenuh (Ulfatin, 2015). Proses analisis data dapat dilihat pada gambar 1.

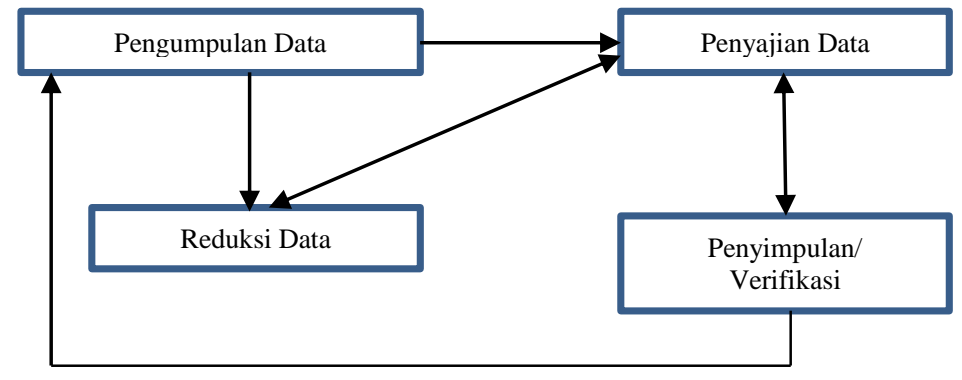

Gambar 1. Analisis Data Model Interaktif (Huberman, 1992)

\section{HASIL}

\section{Program Pembiasaan Penguatan Nilai Karakter Religius}

SD Alam Ar-Rohman memiliki enam program pembiasaan penguatan pendidikan karakter nilai religius. Programprogram pembiasaan yang diterapkan di SD Alam Ar-Rohman Malang yaitu kultum, sholat dhuha, dhuhur dan ashar berjamaah, murojaah, sholat sunah rawatib, dzikir petang, halaqoh ba'da jum'at. Program-program tersebut sesuai dengan visi dan misi sekolah.

\section{Implementasi Program Pembiasaan Penguatan Pendidikan Karakter Nilai Religius}

Program-program pembiasaan di SD Alam Ar-Rohman dilakukan sebagian besar dilakukan secara rutin baik oleh guru maupun siswa. Berikut ini akan dijabarkan implementasi dari setiap program pembiasaan penguatan karakter religius yang dilakukan oleh SD Alam Ar-Rohman Malang.

\section{Kultum}

Dilaksanakan setiap pagi sebelum pembelajaran dimulai (07.15-07.45). Bertujuan untuk memberikan pemahaman kepada peserta didik mengenai suti tauladan dari para nabi. Materi disampaikan oleh guru kelas dan guru PAI secara bergantian setiap hari. Materi/tema bersifat kondisional. Kendala yang dihadapi yaitu siswa mengobrol dengan teman sebangku, terdapat guru yang masih bingung mengenai materi yang disampaikan. Solusi yang dilakukan guru langsung menegur siswa yang mengobrol sendiri, guru yang lain selalu bersiap untuk menggantikan atau menambah materi jika guru yang bersangkutan mengalami kendala terkait dengan materi.

Sholat Dhuha, Dhuhur, dan Ashar Berjamaah

Pelaksanaan sholat dhuha yaitu 07.00 - 07.30, sholat duhur 11.45—12.15 dan sholat ashar 14.55—15.30 dilaksanakan oleh seluruh peserta didik secara berjamaah. Bertujuan untuk membiasakan peserta didik untuk solat tanpa ada paksaan atau suruhan, serta menyempurnakan gerakan serta bacaan sholat peserta didik. Sholat ashar hanya dilaksanakan oleh kelas VI. Kelas rendah melakukan sholat di kelas, sedangkan kelas tinggi melakukan sholat di aula. Imam sholat untuk kelas rendah dilakukan oleh siswa laki-laki secara bergantian sementara untuk kelas tinggi dari pihak guru. Tidak ada kendala yang berarti.

\section{Murojaah}

Dilaksanakan rutin setiap hari sebelum sholat dhuhur. Guru sebagai pendamping. Guru melakukan kerjasama dengan wali murid untuk terus memantau perkembangan hafalan anak. Siswa terus bersemangat dan terus terpacu untuk hafalan AlQuran. Guru sendiri juga semakin berupaya untuk meningkatkan hafalannya. Guru dan kepala sekolah terdapat program khusus untuk murojaah sebelum pulang sekolah. Kendala yang dihadapi yaitu ada beberapa peserta didik yang lamban dalam menghafal karena beberapa faktor tertentu. Solusi yang diberikan guru yaitu melakukan kegiatan pendekatan pada anak di sekolah, adanya program home visit, melakukan kerjasama dengan wali murid, guru memberika metode cepat hafal Al-Qur'an, guru memberikan kisi-kisi ayat-ayat yang harus dihafal oleh peserta didik dalam batas waktu tertentu. 


\section{Sholat Sunnah Rawatib}

Dilaksanakan sebelum dan sesudah sholat wajib. Tempat pelaksanaan menyesuaikan dengan sholat wajib. Bertujuan untuk memberikan pemahaman kepada peserta didik mengenai makna dari pelaksanaan sholat sunnah rawatib memiliki nilai yang luar biasa sebagai penyempurna shalat fardhu. Tidak wajib dilakukan. Dilakukan oleh siswa yang solat fardhunya dirasa tidak sempurna. Kendala: karena merupakan program tidak wajib maka banyak menimbulkan kendala misalnya siswa tidak begitu peduli dan guru kurang dalam mengawasi. Solusi: sekolah selalu mengingatkan akan fungsi dan tujuan dilaksanakannya sholat sunnah rawatib.

\section{Dzikir Petang}

Dilaksanakan setiap hari Sabtu pukul 07.00 - 07.45 bertujuan agar peserta didik hafal bacaan dzikir petang dan mampu mengimplementasikannya di rumah. Dilaksanakan secara bersama-sama seluruh warga sekolah di aula. Sekolah melakukan kerjasama dengan wali murid untuk turut serta menerapkan kebiasaan ini di rumah. Kendala yang dihadapi yaitu program tidak dilaksakan dengan rutin karena tidak ada jadwal yang jelas.

\section{Halaqoh Ba'da Jum'at}

Kegiatan Halaqoh bagi peserta didik laki-laki dan perempuan dilakukan secara terpisah. Halaqoh bagi peserta didik perempuan dilakukan saat siswa laki-laki melakukan sholat jum'at. Halaqoh untuk siswa laki-laki tidak selalu dilakukan. Materi untuk peserta didik perempuan terkait dengan keputrian. Peserta didik sangat antusias dengan kegiatan yang dilakukan. Guru selalu berusaha menyinkronkan materi dengan Al-Qur'an. Kendala yaitu masih banyak peserta didik yang membaca Al-Qur'an tidak sesuai tajwidnya, masih ada peserta didik yang belum lancar membaca Al-Qur'an. Solusi yang diberikan guru yaitu guru memberikan materi tajwid dalam kegiatan Halaqoh.

\section{Dampak Implementasi Program Pembiasaan Penguatan Pendidikan Karakter Nilai Religius bagi Siswa}

Program pembiasaan pendidikan karakter religius yang diterapkan oleh SD Alam Ar-Rahman Malang mempunyai dampak yang signifikan terhadap perilaku serta ketakwaan siswa dalam beribadah. Siswa tidak hanya mampu mengerti serta menjalankan ibadah-ibadah wajib, seperti sholat dan membaca Al-Qur'an, namun juga memahami tujuan dan mafaat dari setiap kegiatan yang dijalaninya. Siswa lebih rajin dan tepat waktu dalam mejalani ibadah, siswa juga bersikap sopan kepada guru dan orangtua. Untuk siswa-siswa yang sebelumnya mengalami masalah di keluarga, misalnya bercerai dan kurang perhatian, dengan adanya program-program penguatan karakter nilai religius ini menjadi lebih tenang. Lebih jauh lagi, peserta didik mampu untuk mengajak orang-orang di sekitarnya untuk beribadah lebih baik dan menjalankan aktivitas sehari-hari sesuai dengan syariat Islam.

\section{PEMBAHASAN}

\section{Program Pembiasaan Penguatan Nilai Karakter Religius}

SD Alam Ar-Rohman yang berlandaskan tauhid, sesuai dengan visi dan misinya sekolah ini mengembangkan berbagai program kegamaan di sekolah. Sekolah melandaskan visi dan misi sekolahnya pada keislaman yaitu karena adanya berbagai problematika yang dihadapi oleh peserta didik. Dengan menggunakan dasar keagamaan yang kuat, sekolah berkeyakinan dapat mengurangi atau bahkan menghilangkan perilaku-perilaku siswa yang menyimpang secara bertahap. Hal serupa juga dinyatakan oleh (Asmaun, 2010) yang menyatakan jika pembelajaran agama islam sebagai salah satu upaya alternatif untuk menciptakan pribadi yang beriman, bertaqwa kepada Tuhan serta berakhlak mulia dalam kehidupan individu, bermasyarakat, berbangsa, dan bernegara.

Salah satu cara yang dapat digunakan oleh sekolah yaitu dengan program pembiasaan atau budaya sekolah. Budaya sekolah merupakan sekumpulan nilai yang melandasi perilaku, tradisi, kebiasaan keseharian, dan simbol-simbol yang dipraktikkan oleh kepala sekolah, guru, petugas administrasi, siswa serta masyarakat sekitar sekolah (Maryamah, 2016; Saminan, 2015). Berdasarkan pernyataan tersebut dapat diketahui jika budaya sekolah juga mencangkup kebiasaan, tradisi serta penggunaan simbol-simbol oleh warga sekolah. Dalam temuan penelitian terdapat enam program yang ditemukan dalam program budaya sekolah terkait dengan program pembiasaan penguatan karakter religius yaitu, kultum, sholat Dhuha, Dhuhur dan Ashar berjamaah, Muroja'ah, sholat sunnah Rawatib, dzikir petang serta Halaqoh ba'da Jum'at. Program-program tersebut dilakukan secara konsisten dan berkelanjutan dan sudah bagian dari kebiasaan warga sekolah.

Program pembiasaan merupakan kegiatan yang berlanjut dan berkesinambungan. Oleh karena itu, dalam pelaksanaannya melibatkan seluruh warga sekolah. Hal tersebut dilakukan guna menjaga konsistensi dari keterlaksaan program serta dampakdampak positif yang ditimbulkannya. Seperti yang diungkap oleh (Wibowo, 2013) bahwa memang dalam pendidikan karakter diutamakan keteladanan dari semua warga dan komponen sekolah, baik kepala sekolah, guru, dan staf harus konsisten dalam kata, sikap, dan perbuatan. 


\section{Implementasi Program Pembiasaan Penguatan Pendidikan Karakter Nilai Religius Kultum}

Pada hakekatnya kultum merupakan kepanjangan dari kuliah tujuh menit (Wisma, 2010). Bertujuan untuk menyampaikan sesuatu kepada orang banyak dengan durasi waktu yang tidak terlalu lama (Zulkarnaini, 2015). Hal ini juga sesuai dengan pernyataan (Lugandi, 1989) menyatakan kultum atau ceramah agama adalah suatu penyampaian informasi yang bersifat searah yaitu dari penceramah kepada hadirin. Hal ini berbeda dengan pendapat (Munsyi, 1981) beliau berpendapat bahwa kultum merupakan sebuah metode yang dilakukan dengan maksud untuk menyampaikan petunjuk, keterangan, pengertian dan penjelasan tentang suatu masalah dihadapan orang banyak. Berdasarkan pengertian di atas dapat disimpulkan bahwa pengertian dari kultum yaitu ceramah agama yang disampaikan secara singkat guna memberikan suatu informasi atau pemahaman.

Pelaksanaan program kegiatan kultum di SD Alam AR Rohmah Malang dilaksankan setiap pagi setelah peserta didik melaksankan sholat dhuha. Pelaksanaan kultum dilakukan oleh guru kelas atau guru PAI secara bergantian dengan tema yang berbeda-beda setiap harinya. Kultum tidak hanya menyampaikan informasi keagamaan saja, tetapi juga membahas yang berkaitan dengan keseharian peserta didik. Jika pada hari itu ada kejadian yang dialami oleh sekolah, misalnya ada peristiwa pencurian dalam kelas maka guru akan membahas kejadian tersebut dalam pelaksanaan kultum dengan memberikan pemahaman dosa jika mengambil sesuatu yang bukan milik sendiri.

Kendala pada peserta didik yaitu terkadang peserta didik sulit untuk dikondisikan saat dimulainya pelaksanaan kultum. Langkah yang dapat dilakukan pada permasalahan tersebut guru bisa memberikan kultum dengan sering mengajak interaksi langsung kepada peserta didik. Supaya peserta didik merasa diperhatikan dan peserta didik yang awalnya ramai menjadi memusatkan perhatikan kepada guru yang memberikan kultum. Kedua, kendala yang dihadapi guru adalah kurangnya persiapan materi dalam pelaksanaan kultum. Guru yang tidak memiliki perencanaan materi pada pelaksanaan kultum terlihat gugup di depan peserta didik dan cara berbicaranya juga kurang lancar karena tidak memiliki perencanaan materi yang matang untuk disampaikan. Hal ini sesuai dengan pernyataan (Ridla, 2008) menyatakan bahwa perencanaan adalah langkah awal bagi sebuah kegiatan dalam bentuk memikirkan hal-hal yang akan disampaikan agar memperoleh hasil yang optimal. Bahwasannya tanpa adanya persiapan maka tidak ada dasar untuk melaksanakan program-program kegiatan tertentu dalam rangka usaha mencapai tujuan.

\section{Sholat Dhuha, Dhuhur, dan Ashar Berjamaah}

Secara bahasa "Dhuha" diambil dari kata Ad-Dhahwu yang atinya siang hari yang memanas. Sholat dhuha merupakan sholat sunnah yang dilakukan ketika matahari mulai terbit (Baits, 2010). Hal ini sependapat dengan (Azzet, 2010) yang mengatakan bahwa waktu sholat dhuha yaitu waktu ketika matahari naik kurang lebih tujuh hasta sejak terbitnya kira-kira pada pukul 07.00 pagi hingga waktu dzuhur. Pelaksanaan sholat dhuha di SD Alam Ar Rohmah Malang dilakukan sekitar pukul 07.10. Sholat dzuhur dan sholat ashar merupakan sholat wajib yang harus dilaksanakan umat Islam, sedangkan sholat dzuhur yaitu sebanyak empat rakaat. Begitu juga sholat ashar yaitu empat rakaat (Arsyad, 2007). Waktu pelaksanaan sholat dzuhur adalah ketika telah tergelincirnya matahari menuju arah tenggelamnya hingga bayangan seseorang sebagaimana tingginya selama sebelum masuk waktu ashar (Al-Husaini, 2007). Penjelasan tersebut sesuai dengan pelaksanaan sholat dzuhur yang dilakukan oleh peserta didik SD Alam Ar Rohmah Malang, yaitu sekitar pukul 11.40 tempat pelaksanaan sholat dzuhur bagi kelas bawah dan kelas atas sama halnya seperti pelaksanaan sholat dhuha, sedangkan pada pelaksanaan sholat ashar hanya dilaksanakan oleh peserta didik kelas VI karena pada kelas tersebut ada tambahan pelajaran sehingga jam pulang sekolah setelah melaksanakan sholat ashar. Waktu pelaksanaan sholat ashar bagi peserta didik kelas VI yaitu sekitar pukul 14.51. Hal itu diperkuat dengan pernyataan dari (Al-Husaini, 2007) menyatakan bahwa pelaksanaan sholat ashar ketika bertambahnya bayang-bayang suatu benda sama dengan panjang benda tersebut dan akhir waktu ashar adalah ketika tenggelamnya matahari.

\section{Murojaah}

Program kegiatan murojaah sebelum sholat dzuhur. Murojaah merupakan kegiatan mengulang kembali pelajaran dan hapalan yang telah dilewati. Murojaah adalah metode yang digunakan untuk menjaga hapalan Al-Quran peserta didik (Alwi, 2008). Kegiatan murojaah yang berulang-ulang mampu membuat peserta didik lebih mudah menghapal bacaan Al-Quran (Nawabuddin, 1991). Menurut (Al-Hafidz) terdapat lima macam cara untuk menghafal Al-Quran, yaitu metode wahdah, kitabah, sima 'i, jama', dan gabungan antara wahdah dan kitabah. Metode wahdah, yaitu menghafal satu persatu terhadap ayat yang hendak dihafalkan. Metode kitabah, menuliskan ayat-ayat yang akan dihafalkan pada secarik kertas kemudian ayat tersebut dibaca hingga lancar dan benar bacaannya. Metode sima' $i$, mendengarkan suatu bacaan untuk dihafalkan. Metode gabungan antara metode wahdah dan kitabah, hanya saja kitabah disini lebih memiliki fungsi sebagai uji coba terhadap ayat-ayat yang telah dihafalkan selanjutnya mencoba untuk menuliskan di atas kertas dengan hafalan pula. Metode jama', cara menghafal yang dilakukan secara kolektif, yaitu ayat yang dihafal secara bersama-sama dipimpin oleh seorang instruktur.

Lima macam cara tersebut sesuai dengan pelaksanaan murojaah yang dilakukan di SD Alam Ar Rohmah Malang. Terlebih dahulu sebelum memulai hafalan, peserta didik diminta untuk menuliskan ayat-ayat yang akan dihafalkan. Satu baris terdiri dari satu ayat. Selanjutnya, guru mencontohkan cara membaca dengan lancar dan benar ayat yang sudah ditulis per masingmasing ayat lalu peserta menirukan bacaan tersebut. Terakhir peserta didik diminta untuk menghafal ayat-ayat yang sudah ditulis, dibaca, dan dihafalkan. Metode tersebut diterapkan oleh guru dan setiap peserta didik mulai melaksanakan kegiatan murojaah. 
Dalam pelaksanaan murojaah pasti terdapat kendala yang dihadapi yaitu pada pelaksanaan program kegiatan murojaah sebelum sholat dzuhur, masih banyak ditemukan peserta didik yang kesulitan untuk menghafal. Langkah untuk mengurangi kendala tersebut guru-guru mengomunikasikan kepada orangtua peserta didik untuk membantu mnghafalkan Al-Quran selama di rumah. Selain itu, guru memberitahukan target yang harus dicapai peserta didik dalam program kegiatan murojaah supaya peserta didik mampu mencapai tujuan yang sudah ditentukan pihak sekolah dalam pelaksanaan kegiatan murojaah. Hal ini sesuai dengan pernyataan (Joan, 2018) bahwa keterlibatan orangtua menjadi pengaruh utama pembentukan karakter anak bahkan sejak dari pendidikan anak usia dini.

\section{Sholat Sunnah Rowatib}

Sholat sunnah rowatib adalah shalat sunnah yang dilakukan sebelum atau sesudah shalat lima waktu (Rifa'i, 2003). Salah satu amalan yang dapat dikerjakan untuk menambah amalan dari ibadah wajib adalah amalan sunnah. Banyak sekali amalan sunnah yang dapat dikerjakan untuk menyempurnakan ibadah, salah satunya adalah sholat sunnah. Pada pelaksanaannya, guru meminta peserta didik yang kurang sempurna dalam pelaksanaan sholat fardhu (berbicara dengan teman disampingnya, tidak khusyu', ramai saat sholat) untuk melaksanakan sholat lagi (sholat sunnah rowatib) sebagai pelengkap sholat fardhu sebelumnya. Guru juga tidak lupa untuk selalu menghimbau kepada seluruh peserta didik lainnya untuk melaksanakan sholat sunnah rowatib. Pelaksanaan sholat sunnah rowatib di SD Alam Ar Rohmah Malang dilakukan saat sebelum dan sesudah sholat dzuhur dan ashar. Terdapat keutamaan sholat sunnah rowatib yang menguntungkan bagi umat Islam. Seperti Hadist Riwayat Muslim (Daud) yaitu ketika seseorang melanggengkan sholat sunnah rowatib, yaitu empat rakaat sebelum sholat dzuhur dan dua rakaat sesudahnya. Dua rakaat sesudah maghrib, dua rakaat sesudah isya, dan dua rakaat sebelum subuh. Allah akan membangunkan sebuah rumah di dalam surga. Meskipun begitu, dalam melaksanakannya harus secara terus menerus. Tidak hanya sekali dalam sehari, besoknya tidak dan terus seperti itu, tetapi dilaksanakan dengan terus menerus sehingga menjadi sebuah kebiasaan.

Kendala yang dihadapi dalam pelaksanaan program kegiatan sholat sunnah rowatib ialah masih banyak peserta didik yang tidak rutin melaksankan sholat sunnah rowatib. Hal tersebut dikarenakan program kegiatan ini memang diperuntukkan bagi peserta didik yang kurang sempurna dalam melaksanakan sholat fardhu. Langkah untuk mengurangi kendala tersebut guru selalu mengingatkan peserta didik sebelum dan setelah sholat fardhu untuk melaksankan sholat sunnah rowatib, tidak lupa pula guru mengajak peserta didik secara bersama-sama dalam melaksankan sholat sunnah rowatib walaupun sholat tersebut hukumnya sunnah. Hal ini sejalan dengan apa yang disampaikan oleh (Yaqub, 1997) bahwa sebelum menyuruh para sahabat untuk melakukan suatu perbuatan, Rasulullah SAW selalu memberikan contoh terlebih dahulu bagaimana melakukan perbuatan tersebut. Metode pemberian contoh atau ajakan sangat efektif karena para sahabat langsung dapat melihat sendiri bagaimana ajaran Rasulullah SAW itu dipraktikkan.

\section{Dzikir Petang}

Program kegiatan selanjutnya adalah dzikir petang. Secara etimologi, dzikir berasal dari bahasa arab yaitu dzakara, yadzakuru, dzikir yang berarti menyebut, mengingat Allah (Bukhori, 2008). Sesuai yang disebutkan dalam Al-Quran (Al Ahzab 33:41) yaitu hai orang-orang yang beriman, berdzikirlah (dengan menyebut nama) Allah, dzikir yang sebanyak-banyaknya. Pelaksanaan dzikir petang di SD Alam AR Rohmah Malang dilaksankan di kelas masing-masing bagi kelas rendah (kelas I, II, dan III), sedangkan pelaksanaan dzikir di ruang aula yaitu bagi kelas tinggi (kelas IV, V, dan VI). Pelaksanaan dzikir dipimpin oleh guru dari masing-masing kelas, kecuali pada kelas tinggi yang bertugas memimpin dzikir adalah pihak yang bertugas pada saat itu, penanggung jawab dalam memimpin dzikir petang sebelumnya sudah ditentukan.

Kendala yang dihadapi dalam program kegiatan dzikir petang yaitu disebabkan dari pelaksanaannya yang tidak rutin dilakukan dan tidak ada jadwal yang tertulis tentang pelaksanaan kegiatan dzikir petang. Langkah untuk mengurangi kendala tersebut pihak guru kelas setiap hari kamis setelah melaksanakan sholat dzuhur melanjutkan untuk dzikir bersama dengan menambahkan materi tentang dzikir petang karena guru beranggapan program kegiatan dzikir tersebut juga salah satu kegiatan penting yang harus tetap dilaksanakan. Sebab seseorang akan merasa hatinya lebih tenang dan damai jika sering menyebut nama Allah. Seperti yang dikemukakan oleh (Tebba, 2004) jika praktik dzikir terus menerus dilakukan, seseorang tidak akan menaruh perhatian pada proses berpikir yang tidak ada ujung pangkalnya. Akan tetapi, jika dzikir tersebut terus berlangsung dan ia akan memusatkan perhatian pada suatu titik. Hati merupakan wahana kesadaran dan memiliki lapisan. Jika dilakukan terus menerus, dzikir akan masuk menembus lapisan demi lapisan yang ada di dalam hati.

\section{Halaqoh Ba'da Jum'at}

Program terakhir yaitu halaqoh ba'da jumat. Halaqoh merupakan proses kegiatan tarbiyah dalam dinamika kelompok dengan jumlah maksimal 12 orang (Qadiri, 1993). Halaqoh bisa juga diartikan sebagai penyampaian tausyiah dan kajian keislaman yang berkumpul secara melingkar (Munawir, 2002). Seperti yang disapaikan (Asrohah, 1999) pelaksanaan halaqoh merupakan suatu proses pendidikan dimana peserta didik mengambil posisi melingkari guru, guru duduk diantara lingkaran tersebut dengan posisi badan tidak ada yang membelakangi. 
Pada pelaksanaan halaqoh yaitu untuk menyampaikan materi ilmu yang beragam. Untuk pelaksanaan halaqoh di SD Alam Ar Rohmah Malang pada kelas tinggi dibedakan antara peserta didik laki-laki dan perempuan. Pelaksanaan halaqoh pada peserta didik perempuan membahas mengenai keputrian, sedangkan peserta didik laki-laki membahas mengenai khutbah yang disampaikan pada saat sholat jumat berjamaah. Kendala yang dihadapi pada saat pelaksanaan halaqoh sangat minim. Penyampaian materinya sudah sesuai dengan yang ditentukan oleh pihak sekolah. Begitu juga pada waktu pelaksanaannya, ketika peserta didik laki-laki melaksanakan sholat jumat, maka peserta didik perempuan juga memulai melaksanakan program kegiatan halaqoh.

\section{Dampak Implementasi Program Pembiasaan Penguatan Pendidikan Karakter Nilai Religius bagi Siswa}

Berbagai jenis program pembiasaan penguatan pendidikan karakter nilai religius yang disusun tersebut memiliki dampak yang signifikan terhadap penguatan karakter religius siswa. Dampak dari implementasi penguatan pendidikan karakter yang ditemukan di SD Alam-Ar-Rohman tebagi menjadi dua yaitu dampak terhadap diri siswa sendiri serta dampak bagi lingkungan siswa yang dirasakan oleh teman maupun keluarga dari siswa. Beberapa dampak yang muncul yaitu siswa tidak hanya mampu mengerti serta menjalankan ibadah-ibadah wajib seperti sholat dan membaca Al-Qur'an, namun juga memahami tujuan dan mafaat dari setiap kegiatan yang dijalaninya. Dampak penelitian yang serupa juga ditemukan oleh (Fitriyaningsih, 2017) yang mana dengan menerapkan keteladan sikap Rasulullah SAW dalam menanamkan karakter religius, siswa tidak hanya mengerti akan ibadah yang dijalankan, namun juga lebih memahami manfaat dan tujuan dari program yang dilakukan sehari-hari.

Dampak dari dalam diri siswa yang muncul selanjutnya adalah siswa lebih rajin, tepat waktu dalam menjalani ibadah sholat, dan membaca serta hafalan Al-Qur'an. Karena siswa terbiasa dengan program-program yang dilakukan dan lingkungan sekolah yang positif membuat siswa semakin bersikap disiplin dan religius. Hasil yang sama terkait dengan temuan ini juga ditemukan oleh (Nugraheni., dkk, 2012). Penelitian tersebut mengungkap jika pembiasaan program-program religius seperti membaca Al-Qur'an mampu meningkatkan nilai religius, toleransi serta disiplin peserta didik. Peserta didik menjadi terbiasa dengan kegiatan yang dilakukan sehingga secara sendirinya akan menumbuhkan kesadaran dalam menjalani ibadah sholat maupun membaca Al-Qur'an secara rutin.

Dampak selanjutnya yang muncul pada diri siswa yaitu bersikap sopan kepada guru dan orangtua. Untuk siswa-siswa yang sebelumnya mengalami masalah di keluarga misalnya bercerai dan kurang perhatian dengan adanya program-program penguatan karakter nilai religius ini menjadi lebih tenang. Hasil temuan ini diperkuat dengan temuan penelitian oleh (Yaqin, 2017) yang menyatakan jika dari hasil kegiatan ektrakulikuler penguatan karakter religius siswa memiliki jiwa sosial yang tinggi. Tidak hanya kepada sesama teman, namun juga kepada guru dan lingkungan sekitar. Semakin berkembangnya sikap toleransi dan peduli antar teman, sikap sopan santun kepada guru serta semakin tingginya rasa hormat kepada guru serta sekian tingginya sikap sosial kepada lingkungan masayarakat yaitu kebiasaan bersedekah yang semakin meningkat. Hasil penelitian tersebut juga memiliki arti siswa semakin mengerti pentingnya nilai-nilai religius serta berusaha menerapkankannya dalam kehidupan sehari-hari.

Program pembiasaan penguatan pendidikan karakter nilai religius yang diterapkan di SD Alam-Ar-Rohman memiliki dampak yang sangat signifikan kepada diri setiap siswanya yaitu pemahaman siswa akan pentingnya dan maanfaat dari ibadah sholat dan membaca serta hafalan Al-Quran, bersikap sopan dan santun, semakin bertanggung jawab pada diri sendiri serta berusaha menjalankan kewajiban berdasarkan syariat islam. Namun, tidak hanya sampai kepada kesadaran pada diri setiap peserta didi saja, lebih jauh lagi peserta didik mampu memberikan pengaruh positif kepada orang-orang di sekitarnya termasuk mampu untuk mengingatkan teman serta saudara untuk beribadah tepat waktu menjalankan aktivitas sehari-hari sesuai dengan syariat Islam yang telah dipelajarinya.

\section{SIMPULAN}

Berdasarkan fokus penelitian dan temuan serta analisis temuan, maka dapat disimpulkan sebagai berikut. Pertama, program-program penguatan pendidikan karakter religius di SD Alam Ar-Rohman sesuai dengan visi dan misi sekolah. Programprogram pembiasaan atau budaya sekolah yang diterapkan di SD Alam Ar-Rohman yaitu kultum, sholat dhuha, dhuhur dan ashar berjamaah, murojaah, sholat sunnah rawatib. Dzikir petang serta halaqoh ba'da Jum'at. Kedua, implementasi program penguatan karakter nilai religius di SD Alam Ar-Rahman sebagian besar dilaksanakan setiap hari secara rutin. Program yang dilaksanakan rutin setiap hari yaitu kultum, sholat dhuha, dhuhur dan ashar berjamaah, morojaah, sholat sunnah rawatib, sedangkan halaqoh ba'da jum'at dilaksanakan setiap hari Jum'at dan dzikir petang dilaksanakan setiap hari sabtu. Setiap progam dilaksanakan secara bergantian dan memiliki kendalanya masing-masing. Dalam setiap pelaksanaan siswa sangat antusias dan memiliki kesadaran yang tinggi untuk melaksanakan setiap kegiatan. Guna kelancaran pelaksanaan sekolah selalu meminta kerjasama dengan wali murid. Tujuan lain dari pelibatan wali murid adalah untuk mendapatkan hasil yang maksimal dan berkelanjutan.

Ketiga, dampak dari implementasi penguatan pendidikan karakter nilai religius terbagi menjadi dua, yaitu dampak bagi diri siswa sendiri dan bagi lingkungan peserta didik. Dampak yang tampak pada diri peserta yaitu peserta didik semakin sopan pada guru dan orangtua, semakin rajin sholat dan tepat waktu, hafalan Al-Qur'an semakin banyak dan peserta didik terlihat semakin semangat, siswa lebih bertanggung jawab terhadap dirinya sendiri, lebih menutup aurat serta berusaha untuk menjalankan kehidupan sehari-hari sesuai dengan syariat Islam yang telah dipelajarinya. 
Sementara itu, dampak bagi lingkungan peserta didik yaitu semakin meringankan orangtua karena anak memiliki kesadaran yang tinggi akan kebutuhan beribadah, peserta didik dapat memberikan contoh yang baik bagi keluarga dan saudara terkait dengan aspek-aspek keagamaan. Peserta didik juga mampu untuk mengajak atau mengingatkan orang yang lebih dewasa darinya untuk bertingkah laku lebih baik berdasarkan syariat Islam sesuai dengan apa yang telah dipelajari di sekolah. Sekolah perlu membuat jadwal untuk setiap program secara matang supaya pelaksanaannya dapat dilaksanakan sesuai dengan jadwal yang sudah dibuat sejak awal. Melalui perencanaan yang dilakukan oleh sekolah dengan melibatkan peran serta wali murid sehingga implementasi penguatan pendidikan karakter nilai religius dapat dilaksanakan sesuai dengan visi dan misi sekolah yaitu membangun peradaban Islam melalui pendidikan integral berbasis tauhid yang menjadi rujukan umat dan menjadikan generasi yang bertakwa, cerdas, mandiri, dan berwawasan global.

\section{DAFTAR RUJUKAN}

Aeni, A. N. (2014). Pendidikan Karakter untuk Siswa SD dalam Perspektif Islam. Jurnal Publikasi, 1(1), 50-58.

Al-Husaini (2007). Kifayatul Akhyar Fi Halli Gayatul Ikhtihsar diterjemahkan Syarifuddin Anwar dan Mishbah Musthafa, Kifayatul Akhyar (Kelengkapan Orang Saleh). Surabaya: CV Bina Iman.

Alwi, H. (2008). Kamus Besar Bahasa Indonesia. Jakarta: Balai Pustaka.

Arsyad, A. (2007). Media Pembelajaran. Jakarta: Rajagrafindo Persada.

Asmaun, S. (2010). Mewujudkan Budaya Religius di Sekolah: Upaya Mengembangkan PAI dari Teori ke Aksi. Malang: UIN Maliki Press.

Asrohah, H. (1999). Sejarah Pendidikan Islam. Jakarta: Logos.

Azzet, A. (2010). 7 Cara Agar Rezeki Semakin Bertambah dan Barakah (Dalam Bahasa Indonesia). Yogyakarta: Diva Press. Baits, A. (2010). Fikih Sholat Dhuha. Yogyakarta: Pustaka Muslim.

Bukhori, B. (2008) Zikir Al-Asma' Al-Husna: Solusi Atas Problem Agresivitas Remaja, Syiar. Semarang: Media Publishing. Fitriyaningsih, K. (2017). Kontrol Sosial Dalam Pembinaan Karakter Religius Peserta Didik Muslim di Sekolah Menengah Kejuruan Negeri 1 Dukuhturi Kabupaten Tegal. Jurnal Sosiologi Reflektif, 12(1), 87-96.

Ganiere, C., Howell, S. L., \& Osguthorpe, R. (2007). Like Produces Like: John Heyl Vincent and His $19^{\text {th }}$ Century Theory of Character Education. Journal of College and Character, 8, 1-9.

Huberman, A. M. (1992). Analisis Data Kualitatif: Buku Sumber tentang Metode-Metode Baru. Jakarta: UI Press.

Hurlock, E. B. (2006) Psikologi Perkembangan: Suatu Pendekatan Sepanjang Rentang Kehidupan (Edisi Kelima). Jakarta: Erlangga.

Inanna. (2018). Peran Pendidikan dalam Membangun Karakter Bangsa yang Bermoral. Jurnal Ekonomi dan Pendidikan, 1(1), 27-33.

Maryamah, E. (2016). Pengembangan Budaya Sekolah. Jurnal Tarbawi, 2(02), 86-96.

Munsyi, A. (1981). Metode Diskusi dalam Dakwah. Surabaya: Al-Ikhlas.

Nawabuddin. (1991). Teknik Menghafal Al-Quran. Bandung: Sinar Baru.

Qadiri, A. (1993). Adab Halaqah. Bandung: PT. Al-Ma'arif.

Ramdhani, M. A. (2013). Lingkungan Pendidikan dalam Implementasi Pendidikan Karakter. Jurnal Pendidikan Universitas Garut, 8(1), 28-37.

Ramli, M. (2011). Pedoman Pelaksanaan Pendidikan Karakter: Berdasarkan Pengalaman Disatuan Pendidikan Rintisan. Jakarta: Badan Penelitian dan Pengembangan Kurikulum dan Perbukuan Kemendiknas RI.

Retnanto, A. (2013). Model Pengembangan Karakter melalui Sistem Pendidikan Terpadu Insantama Bogor. Jurnal Stain Kudus, $8(2), 249-270$.

Ridla, M. R. (2008). Perencanaan Dalam Dakwah Islam. Jurnal Dakwah, 9(2), 149-162.

Rifa'i, M. (2003). Tuntunan Sholat Lengkap. Semarang: Thoha Putera.

Samani, M. (2011). Konsep dan Model Pendidikan Karakter. Bandung: PT Remaja Rosdakarya.

Saminan. (2015). Internalisasi Budaya Sekolah Islami di Aceh. International Multidisciplinary Journal, 3(1), $147-164$.

Tebba, S. (2004). Meditasi Sufistik. Bandung: Pustaka Hidayah.

Wibowo, A. (2013). Manajemen Pendidikan Karakter di Sekolah. Yogyakarta: Pustaka Belajar.

Yaqin, M. A. (2017) Penguatan Karakter Religius Berbasis Kegiatan Ekstrakurikuler Furudh Al 'Ainiyah pada Siswa SMP Nurul Jadid Paiton Probolinggo. Tesis tidak diterbitkan. Universitas Islam Negeri Maulana Malik Ibrahim, Malang.

Zulkarnaini. (2015). Dakwah Islam di Era Modern. Jurnal Risalah, 26(3), 151-158. 